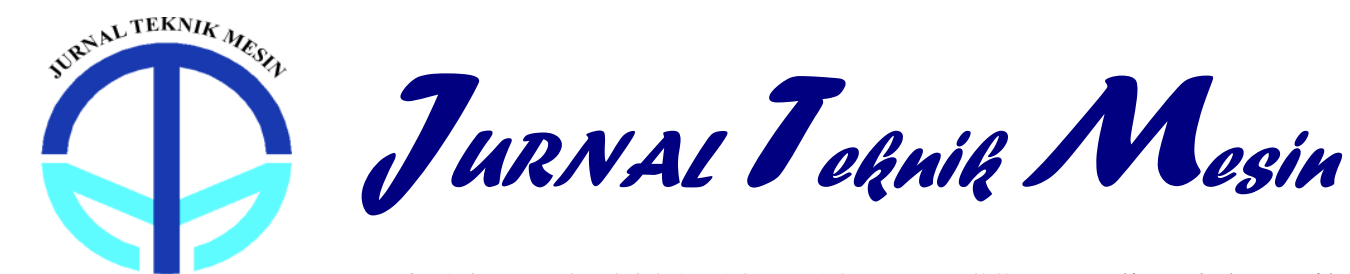

\title{
Combustion Conduct Of A Single-Cylinder Spark-Ignition Affected By Ethanol Fuel Mixtures of Supplement Hydroxy Gas (HHO)
}

\author{
Navik Kholili ${ }^{1}$, Gatot Setyono ${ }^{2}$ \\ ${ }^{1,2}$ Departement of Mechanical Engineering, Faculty of Engineering, Wijaya Putra University (UWP) \\ ${ }^{1}$ navikkholili@uwp.ac.id ${ }^{2}$ gatotsetyono@uwp.ac.id
}

\begin{abstract}
Ethanol is an alternative fuel to replace fossil fuels. The high octane value of ethanol can be used as a substitute for fuel in spark-ignition engines (SI). Gasoline mixed with ethanol will reduce the calorific value resulting in an increase in the combustion process in the combustion chamber. We can find out the improvement in SI engine performance through the engine performance test. Several essential variables can improve engine performance, such as gasoline-ethanol variations, iridium spark plugs, and hydroxy gas generators (HHO). In this study, an experimental method was used by utilizing variations in gasoline (Octane-92)-Ethanol $(35 \%, 45 \%$, and $55 \% \mathrm{v} / \mathrm{v})$ with the intake of hydroxy gas during the combustion process. The SI automatic transmission engine has a capacity of 124.8 cubic centimeters (one cylinder-four stroke), a compression ratio of 11/1, fuel injection, and iridium spark plugs. Test engine performance using chassis dynotest with 4000$9000 \mathrm{rpm}$ engine speed variations. The purpose of this study was to produce optimal engine performance (power, torque, specific fuel consumption, sufficient pressure, and thermal efficiency) for the use of ethanol fuel variations with hydroxyl gas intake. This research resulted in optimal performance of the 55\% gasoline-ethanol mixture concerning the increase in output power, sufficient pressure, and thermal efficiency with an engine speed of $8000 \mathrm{rpm}$. This is in contrast to the specific fuel consumption under the same conditions, which has decreased
\end{abstract}

Keywords: Ethanol, Hydroxy gas, Gasoline-ethanol, Automatic transmission, Engine performance

\begin{abstract}
Abstrak
Etanol merupakan bahan bakar alternatif pengganti fosil fuel. nilai oktan etanol yang tinggi bisa dipakai sebagai pengganti bahan bakar pada spark ignition engine (SI). Bensin yang dicampurkan etanol akan menurunkan nilai kalor mengakibatkan peningkatan proses pembakaran pada ruang bakar. Melalui uji performa mesin dapat mengetahui peningkatan kinerja mesin SI. Ada beberapa variabel penting yang dapat meningkatkan performa mesin seperti variasi bensin-etanol, busi iridium dan generator gas hydroxy (HHO). Pada penelitian kali ini menggunakan metode eksperimen dengan memanfaatkan penggunaan variasi bensin (Oktan-92)-Etanol (35\%, 45\% dan 55\% v/v) dengan asupan gas hydroxy pada saat proses pembakaran. Mesin transmisi automatis SI yang digunakan mempunyai kapasitas 124.8 centimeter-kubic (satu silinder-empat langkah), rasio kompresi 11/1, fuel injeksi dan busi iridium. Uji performa mesin menggunakan dynotest sasis dengan variasi kecepatan mesin 4000-9000 rpm. Tujuan penelitian ini untuk menghasilkan performa mesin (daya, torsi, konsumsi bahan bakar spesifik, tekanan efektif dan efisiensi termal) yang optimal terhadap pemakaian variasi bahan bakar etanol denga asupan gas hydroxyl. Penelitian ini menghasilkan performa yang optimal pada campuran bensin-etanol 55\% terhadap kenaikan daya output, tekanan efektif dan efisiensi termal dengan kecepatan mesin $8000 \mathrm{rpm}$. Hal itu bertolak belakang dengan konsumsi bahan bakar spesifik dengan kondisi yang sama telah mengalami penurunan.
\end{abstract}

Kata kunci: Etanol, Gas hydroxy, Bensin-etanol, Transmisi otomatis, Performa mesin

\section{Introduction}

The depletion of petroleum reserves and increasing air pollution encourage the development and search for alternative and renewable energy founts to degrade current oil dependency. Natural gas has been an excellent alternative to fuels derived from traditional petroleum, as gasoline and diesel. Gas fuel has been utilized effectively anytime like the fuel in many engines, mainly because the energy is plentiful in the world and excavation is cheap [1]. The Trending global attention towards reduced fuel consumption and spark ignition engine emissions encourages researchers to discover reserve solutions that unnecessary engine design modifications. These solutions utilized $\mathrm{H}_{2}$ as a fuel of alternative that 
increases the efficiency engine and results from deficient defilement [2]. The gas was not decent from the mercantile spot of sight, structure a method that produces hydrogen and merging it by an internal combustion engine results in a high cost of production [3]. The Petrol streamflow was degraded by $\mathrm{H}_{2}$ increasing - to keep fixed global mix equality and oppose engine achievement by pure petrol, lower contents of $\mathrm{HC}$ emissions are served in the petrol, which deducts build-up of $\mathrm{CO}_{2}, \mathrm{HC}$ and $\mathrm{CO}$, it improves the economy of petrol consumption. $\mathrm{H}_{2}$ has a more significant spread coefficient than gasoline, so that $\mathrm{H}_{2}$ gas may dissolve entirely in the expense and allows for considerable blend combustion and homogenity perfection. Moreover, increased NOx gas associated with a higher temperature of adiabatic blaze than hydrogen [4].

The Hydrogens have a higher speed of a flame, and the gasoline mixture burns faster. However, as the hydrogen supplement widens the flammability confine of a mix to an equivalent of leaner gasoline, the response rate is degraded, and combustion is extended in poor terms. Therefore, the timing effect of the spark was inquired [5]. The influence of adding hydroxy gas on the compression of ignition engine can increase the torque of machine by an average of $19 \%$, reduce respective Hydrocarbon and $\mathrm{CO}$ emissions, the fuel consumption of specific was decreased by an average of $5 \%, 13 \%$, and $14 \%$ [6]. Research has been conducted on a gasoline engine with a cylinder capacity of 125-centimeter cubic, using RON-90 fuel and cold-type spark plugs on engine speed variations between 4000-9000 rpm. Research data has been taken in the form of torque, fuel consumption, and exhaust gas. The results have concluded that the use of cold-type spark plugs-RON-90 compared to the hot-type spark plugs at range 7000-9000 rpm allows an increase in power, torque, break mean pressure, and thermal efficiency severally by $5.5 \%$, a decrease in specific fuel consumption by $3.3 \%$, reduction of $\mathrm{CO}$ and $\mathrm{HC}$ exhaust emissions of $4.2 \%$ [7]. The application of RON-88 fuel to a gasoline engine with a cylinder capacity of 110 cubic centimetres has resulted in increased engine performance. The results showed a significant increase in torque, power, and sufficient pressure of $4.84 \%, 6.43 \%$, and $6.43 \%$. It has been shown that the fuel mixture affects engine performance [8].

The fuel has a value of octane number (RON-90) has characteristics similar to ethanol. This research has identified the automatic transmission system's engine performance 115 centimetres-cubic with an ethanol fuel mixture using cold-type spark plugs. The results of this research have shown that the $35 \%$ fuel-ethanol mixture with an engine speed range of $7000 \mathrm{rpm}$ has produced maximum performance, namely power of $4.25 \mathrm{~kW}$, a torque of $5.80 \mathrm{Nm}$, the specific fuel consumption of $0.46 \mathrm{~kg} / \mathrm{kW} . \mathrm{h}$, the average adequate pressure is $628.88 \mathrm{kPa}$. The thermal efficiency is
$23.70 \%$, while the $45 \%$ fuel-ethanol mixture at 7000 rpm engine speed has maximum performance, namely power of $4.40 \mathrm{~kW}$, a torque of $6.98 \mathrm{Nm}$, the specific fuel consumption of $0.43 \mathrm{~kg} / \mathrm{kWh}$, sufficient pressure, an average of $756.86 \mathrm{kPa}$, and thermal efficiency of $27.7 \%$ [9]. This research has conducted experiments to detect the effect of RON-90 fuel by modifying the exhaust shape on motorbikes, including the standard type, $3 \mathrm{v} 3$ type, and the scorpion type. The increased torque and power indicated the effect of the exhaust on motorcycle performance. This study has shown the impact of the geometry or shape of the exhaust on reducing noise from the combustion process's output. The use of the $3 \mathrm{v} 3$ type exhaust has consolidated power and torque to the engine. Besides, 3v3 type exhaust has increased the ratio of noise pollution resulting from the combustion process [10].

This research has been implemented on the SI engine, with a capacity of 124.8 centimetres-cubic. It used CR of 9.3:1, fuel injection system and the Euro 3 system, commercial fuels that have been used by RON-95 and ethanol $(25 \%, 35 \%$, and $45 \%)$. Experiments were carried out using spark plugs without electrodes; variations in engine speed to be observed ranged from 4000-9000 rpm. It gained The power, Bmep, and thermal efficiency range for the gasoline-ethanol $(45 \%)$ mixture operated at $7000 \mathrm{rpm}$. A valuable reduction in SFC has been observed in the gasolineethanol mix (45\%) [11]. HHO-ethanol blends have been used in SI machines to measure performance. This research has divided the ratio of fuel-ethanol$\mathrm{HHO}$ addition $(30 \%, 40 \%$, and $50 \%)$ at $4000 \mathrm{rpm}-$ $9000 \mathrm{rpm}$ engine speed, using platinum electrode spark plugs. This research has analyzed, among others, torque, power, Bmep, thermal efficiency and Sfc. The results show that the fuel-ethanol-HHO mixture $(50 \%)$ can increase the strength, average adequate pressure, and thermal efficiency by $5 \%$ (7200 rpm). The specific fuel consumption has decreased by $6 \%$ for the fuel-ethanol-HHO mixture (50\%) [12].

Several researchers apply that ethanol tends to increase torque, power, reduce fuel consumption and exhaust emissions. It was investigated to compensate for the analysis of the structural overhaul of the SI machines. Addition of the fuel-hydrogen-ethanol mixture. However, previously the method of adding HHO with a variety of ethanol fuel $(30 \%, 40 \%$, and $50 \%$ ) had been carried out using the SI-automatic engine. It motivates to develop this research by changing the large capacity engine 124.8-centimetre cubic and the variation of fuel-ethanol-HHO to $(35 \%$, $45 \%$, and $55 \%$ ) so that with the hope of changing the scheme, it can produce maximum engine performance. Another motivation for this research to replace fossil fuels with ethanol-hydrogen is environmental and human health concerns. This research's main objective is to mix fuel-ethanolhydroxy gas without changing the structure of the test 
machine. Thus, it would optimize the performance due to the application of alternative energy blends.

\section{Test procedure and the experiment method.}

\subsection{HHO gas generator.}

The process of installing the component $\mathrm{HHO}$ generator in the experiment has been described in Figure 1. The first thing that must be done is to prepare the appropriate water, then flow it to the HHO cell (1). An electrolysis process occurs in the HHO generator cell, converting $\mathrm{H}_{2} \mathrm{O}$ water to produce hydrogen gas $\left(\mathrm{H}_{2}\right)(2)$. The gas that comes out is channelled into a separation tank (the function of the separator tank is to separate pure hydrogen gas and avoid backfire) (3), then the outlet of the separation tank is channelled through a flowmeter and a hose to the air inlet (engine manifold) (4).

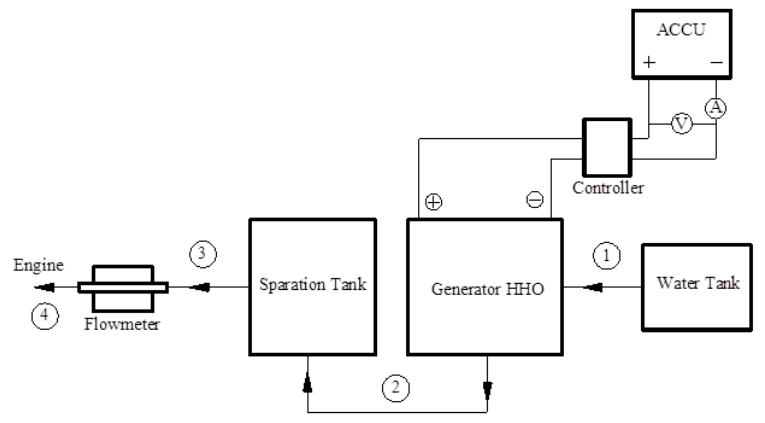

Figure 1. Schematic of component HHO gas system.

\subsection{Fuel Test.}

This research will use three variations of fuel. Table 1 shows the distribution of fuel mixed with RON-92 as the primary fuel (E0). The ethanol to be mixed has $35 \%, 45 \%$, and $55 \%$ v/v (E35, E45, and E55). This experiment is a continuation of previous studies which contain a lower percentage of ethanol. Table 1 shows that the ethanol-gasoline mixture can increase the fuel's density and viscosity properties, affecting the increase in the octane value of the fuel.

Table 1. Properties of the blended fuels.

\begin{tabular}{|c|c|c|c|c|c|c|}
\hline $\begin{array}{c}\text { Measured } \\
\text { Component }\end{array}$ & Unit & Reference & E0 & E35 & E45 & E55 \\
\hline Viscosity & $\mathrm{mm}^{2} / \mathrm{s}$ & $\begin{array}{c}\text { ASTM } \\
\text { D-445-97 }\end{array}$ & 0,51 & 0,55 & 0,58 & 0,60 \\
\hline Density & $\mathrm{g} / \mathrm{cm}^{3}$ & $\begin{array}{c}\text { ASTM } \\
\text { D-1298 }\end{array}$ & 0,732 & 0,782 & 0,791 & 0,798 \\
\hline $\begin{array}{l}\text { Low } \\
\text { Heating } \\
\text { Value }\end{array}$ & $\mathrm{kJ} / \mathrm{kg}$ & $\begin{array}{l}\text { ASTM } \\
\text { D-240 }\end{array}$ & 44472 & 37105 & 34878 & 31876 \\
\hline
\end{tabular}

Previous researchers did the mixture of gasolineethanol with a mixing percentage of $30 \%, 40 \%$, and $50 \% \mathrm{v} / \mathrm{v}$, and it has had a maximal effect to increase the octane value because of the density and viscosity properties increase along in the addition of ethanol to the fuel. A considerable octane value can be expected to produce the maximum combustion process on the SI engine [12].

\subsection{Engine Properties.}

This research uses the SI machine specifications, as shown in Table-2. The SI engine uses one cylinder with four strokes; the engine has $124,8 \mathrm{~cm}^{3}$ and uses iridium electrode spark plugs.

Table 2. Specification of Engine SI.

\begin{tabular}{lc}
\hline \multicolumn{1}{c}{ Exact Details } & Specifications \\
\hline Displacement & $124,8 \mathrm{~cm}^{3}$ (4-strokes) \\
CR & $11: 1$ \\
Maximum power & $8,2 \mathrm{~kW} / 8.500 \mathrm{rpm}$ \\
Weight & $111 \mathrm{~kg}$ \\
Cooling system & Air cooling \\
Fuel system & Programmed Fuel Injection (PGM-FI) \\
Transmission & Otomatic, V-Matic \\
Coopling & Automatic Centrifugal Clutch Dry Type \\
Spark plugs & Iridium \\
\hline
\end{tabular}

Previous researchers have carried out the use of automatic transmission machines. Testing the engine using a capacity of $109.5 \mathrm{~cm}^{3}$, fuel injection system, and the compression ratio is 10:1, this machine SI has a maximum power of $6.6 \mathrm{~kW} / 7500 \mathrm{rpm}$ and uses platinum electrode spark plugs [12]. Previous research is almost the same as using the SI engine, when the experiment has used a conventional SI transmission engine with a capacity of $124.8 \mathrm{~cm} 3$, compression ratio (CR) 9.3: 1, the machine uses iridium electrode spark plugs, maximum power of $7.4 \mathrm{~kW} / 8000 \mathrm{rpm}$ [11].

\subsection{Spark Ignition Engine-Matic Test.}

Performance testing of automatic gasoline motorbikes has been carried out at the ITATS Surabaya. The test instrument used is a single roller chassis dynamometer with the type Sport-Dyno 3.8, according to Figure-2 shown. This machine test is carried out at the engine spin speed division between 4000 to 9000 rotations per minute. The first test flow is by identifying the quantity of the fuel mixture entering the manifold. The fuel mixture is directed to the injector, which will be forwarded to the combustion chamber, then the combustion process occurs, affecting engine speed. The test is observed on the chassis dynamometer and displayed as a power or torque graph on the CPUSportDyno 3.8. 


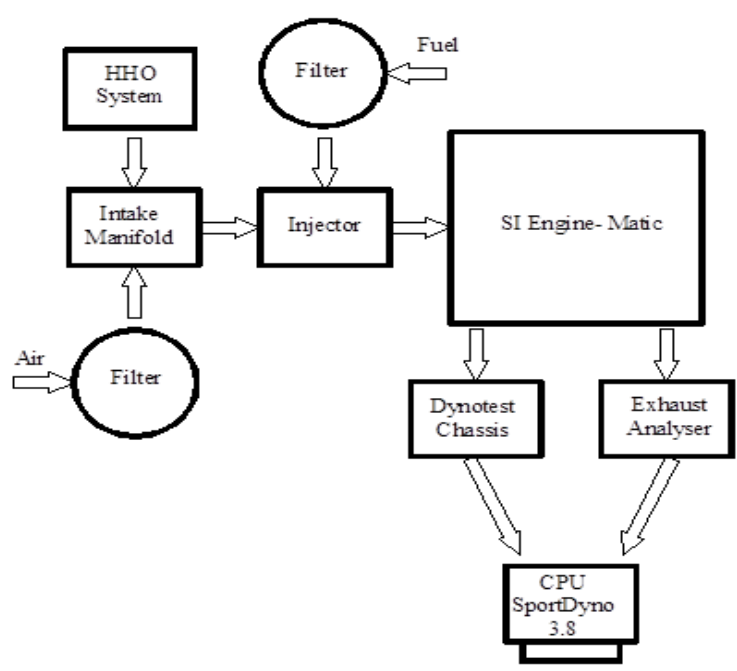

Figure 2. SI Engine Matic set-up.

\section{Result And Discussion.}

Output power is a measure of the SI engine capability, the level of fuel intake is very influential on the quality of the combustion process, therefore in this research, it is necessary to innovate again by adding HHO-ethanol as a fuel supplement. Figure 3 shows that the addition of ethanol-HHO can increase the power of the engine. The mixture of fuel and ethanol has a low calorific value resulting in an increasing combustion process and engine speed. the output power of $8.1 \mathrm{~kW}$ has increased at $8200 \mathrm{rpm}$ engine speed. the ethanol-HHO fuel mixture increased by $3 \%$ (E33), 3\% (E45) and 4\% (E55). in Figure 4, the highest value of the fuel mixture affects the average effective pressure that occurs in the combustion chamber, and this is due to the increasing octane value of the fuel. The increase in power output is directly proportional to the intensified pressure in the combustion chamber.

Previous research also stated that the addition of ethanol to gasoline followed by the supply of HHO in the combustion chamber had affected the combustion rate in the combustion chamber; it affects the increase in output power [12].

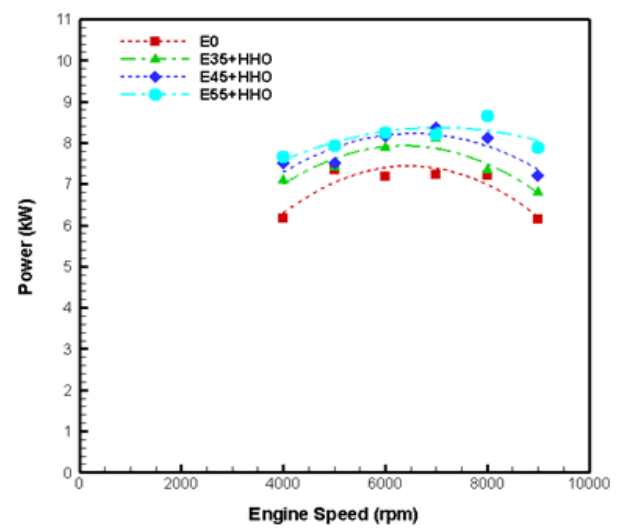

Figure 3. Variety of power to engine speed

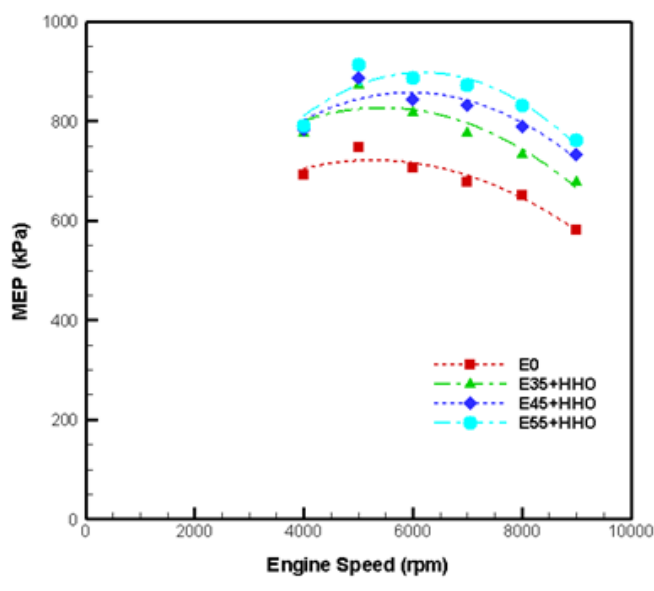

Figure 4. Variety of Mean pressure to engine speed.

The mixture of gasoline-ethanol can affect changes in specific fuel consumption. It can be shown in Figure 5 , a mixture of ethanol in power can reduce the heating value and increase the octane value so that it has an impact on the combustion process, which grows in the combustion chamber. This condition also affects the state of the specific FC, which decreases. The ethanol-gasoline mixture $(55 \%)$ decreased by $4 \%$ against the standard fuel, then the ethanol-gasoline mix $(35 \%$ and $45 \%)$ respectively reduced by $3 \%$ and $2 \%$ against the standard fuel. Thermal efficiency changes depending on the output power and input power that occurs in the combustion chamber. The output power is shown from the movement of the engine shaft mechanism connected to the motorcycle wheel, while the input power is shown from the entry of the fuel-ethanol and air mixture into the combustion chamber. Then the efficiency value is directly proportional to the output power, and the thermal efficiency increases along with the output power generated. The ethanol-gasoline mixture (55\%) increased by $3.5 \%$ against the standard fuel, then the ethanol-gasoline $\operatorname{mix}(35 \%$ and $45 \%$ ) respectively reduced by $2 \%$ and $1.5 \%$ against the standard fuel. This phenomenon is shown in Figure 6.

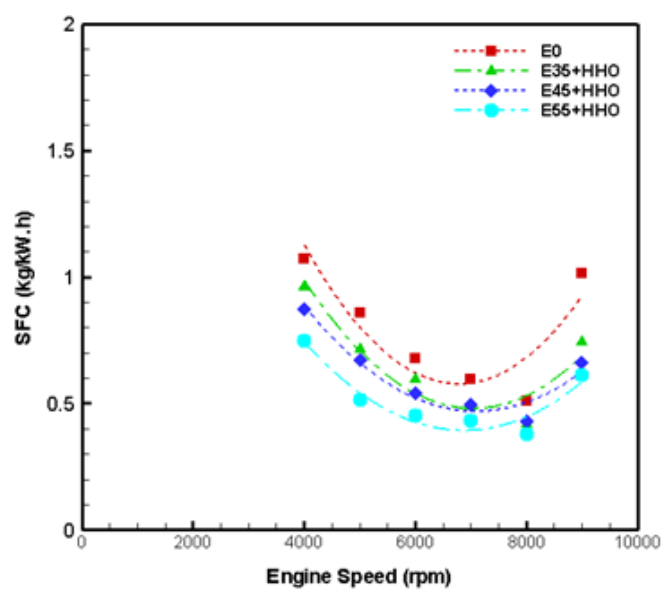

Figure 5. Variety of Specific FC to engine speed 


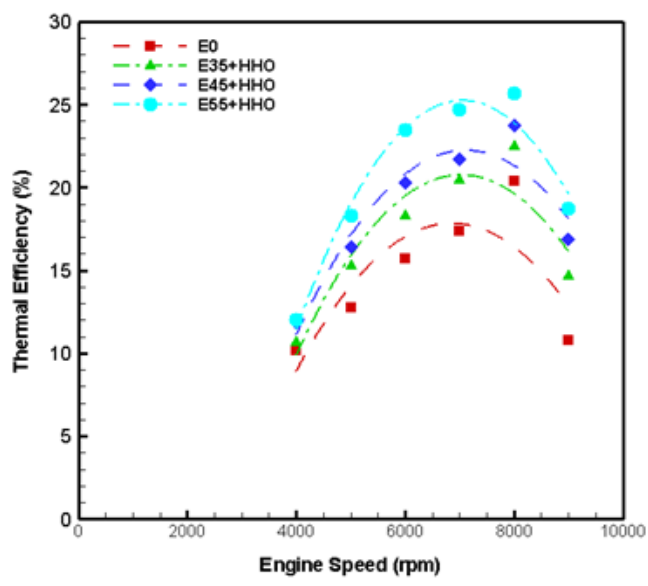

Figure 6. Variety of Efficiency to engine speed.

\section{Conclusion.}

This research shows a four-stroke (1-cylinder) combustion engine performance; several conclusions can be drawn.

1. Ethanol mixture fuel is an optimal alternative to gasoline in spark-ignition engines.

2. A balanced combination of the mixture of fuel and air that enters the combustion chamber will impact the combustion process. Optimal iridium spark plugs help ignite when the gasoline-ethanol and HHO mixture occurs for a complete combustion process.

3. The engine performance test resulted in maximum output power and efficiency in a 55\% ethanolgasoline mixture with an engine speed of 8000 rpm, respectively $8.65 \mathrm{~kW}$ and $26 \%$. The average adequate pressure of the maximum increase occurs at $5000 \mathrm{rpm}$ rotation of $913 \mathrm{kPa}$. Specific fuel consumption has decreased by at least 0.38 $\mathrm{kg} / \mathrm{kWh}$.

The use of variables such as variations in fuel, spark plugs, and HHO generators will affect the performance of the SI engine. Future research needs to consider other variable factors such as the number of cylinders, compression ratio, cylinder capacity, ignition timing, etc., which impact SI engine performance.

\section{References.}

[1] R. Chandra, V. K. Vijay, P. M. V. Subbarao, and T. K. Khura. 2011. Performance evaluation of a constant speed IC engine on $\mathrm{CNG}$, methane enriched biogas and biogas. Appl. Energy, vol. 88, no. 11, pp. 3969-3977. doi: 10.1016/j.apenergy.2011.04.032.

[2] A. Boretti. 2010. Comparison of fuel economies of high efficiency diesel and hydrogen engines powering a compact car with a flywheel based kinetic energy recovery systems. Int. J. Hydrogen Energy, vol. 35, no. 16, pp. 8417-8424. doi: 10.1016/j.ijhydene.2010.05.031.

[3] C. M. White, R. R. Steeper, and A. E. Lutz. 2006. The hydrogen-fueled internal combustion engine: a technical review. Int. J. Hydrogen Energy, vol. 31, no. 10, pp. 1292-1305. doi: 10.1016/j.ijhydene.2005.12.001.

[4] C. Ji and S. Wang. 2009. Effect of hydrogen addition on combustion and emissions performance of a spark ignition gasoline engine at lean conditions. Int. J. Hydrogen Energy, vol. 34, no. 18, pp. 7823-7834. doi: 10.1016/j.ijhydene.2009.06.082.

[5] C. Ji, S. Wang, and B. Zhang. 2010. Effect of spark timing on the performance of a hybrid hydrogen-gasoline engine at lean conditions. Int. J. Hydrogen Energy, vol. 35, no. 5, pp. 2203-2212. doi: 10.1016/j.ijhydene.2010.01.003.

[6] A. C. Yilmaz, E. Uludamar, and K. Aydin. 2010. Effect of hydroxy (HHO) gas addition on performance and exhaust emissions in compression ignition engines. Int. J. Hydrogen Energy, vol. 35, no. 20, pp. 11366-11372, doi: 10.1016/j.ijhydene.2010.07.040.

[7] Gatot Setyono; D. S. Kawano. 2014. Pengaruh Penggunaan Variasi Elektroda Busi terhadap Performa Motor Bensin Torak 4 Langkah. Saintek, vol. 11, no. 2, pp. 69-73.

[8] G. Setyono and D. Sungkono. 2013. Pengaruh Penggunaan Busi Berelektroda Nikel, Platinum Dan Iridium Terhadap Performa Motor Bensin Torak Spark Ignition Engine (SIE) 4 Langkah 1 Silinder. Prosiding Seminar Nasional Manajemen Teknologi XIX. November 2013, pp. A21-A29.

[9] G. Setyono and Y. P. H. S. 2019. Efek Penambahan Bahan Bakar Research Octane Number (RON) 90Ethanol dengan Pemakaian Busi Tipe Dingin terhadap Performasi Mesin Matic 115 CC 1 Silinder. Saintek, vol. 16, no. 1 , pp. 51-56.

[10] G. Setyono, M. Ulum, and Z. Lillahulhaq. 2021. An experiment on different type of muffler on spark Ignition engine $110 \mathrm{cc}$ performance. IOP Conf. Ser. Mater. Sci. Eng., vol. 1010, no. 1, p. 012015, Jan. 2021. doi: 10.1088/1757-899X/1010/1/012015.

[11] G. Setyono and A. A. Arifin. 2019. Effect of EthanolGasoline Mixes on Performances in Last Generation Spark-Ignition Engines Within the Spark-Plug No Ground-Electrodes Type. Mek. J. Tek. Mesin, vol. 5, no. 02, pp. 19-26. doi:10.12345/jm.v5i02.3003.g2577.

[12] G. Setyono. 2020. Hydroxy Gas (HHO) Supplement of Ethanol Fuel Mixture In A Single-Cylinder SparkIgnition Matic-Engine. J. Mech. Eng. Mechatronics, vol. 5, no. 2, pp. 114-121. doi: 10.33021/JMEM.V5I2.1136. 